Economics Development Analysis Journal 6(1)(2017)

\title{
Determinant Analysis of Decrease In Manufacturing Export Value Amid Depreciation of Rupiah Exchange Rate
}

\section{Nanik Ika Nurhayati ${ }^{\bowtie}$}

Economics Development Department, Economics Faculty, Universitas Negeri Semarang

\begin{tabular}{|c|c|}
\hline Article Info & Abstract \\
\hline $\begin{array}{l}\text { Article History: } \\
\text { Received October } 2017 \\
\text { Accepted December } 2017 \\
\text { Published February } 2017\end{array}$ & $\begin{array}{l}\text { Indonesia uses a system of floating exchange rate. The depreciation of the exchange rate, in which } \\
\text { the value of domestic currency decreases and the value of foreign currency increases, will increase } \\
\text { the export. The high depreciation of Rupiah should be able to increase the competitiveness of } \\
\text { Indonesia's export products, especially the manufacturing exports that have the greatest contribution } \\
\text { to the total exports. However, what has happened in recent years is very different. The depreciation } \\
\text { of Rupiah value cannot spur the value of Indonesia's manufacturing exports. Based on the fact } \\
\text { above, the research is entitled "Determinant Analysis of Decrease in Manufacturing Export Value } \\
\text { amid Depreciation of Rupiah Exchange Rate. This research uses time series secondary data for the } \\
\text { quarterly period of 2006Q1-201Q3 that is obtained from Bank Indonesia, International Financial } \\
\text { Statistics, and World Bank. The analytical technique used is the OLS (Ordinary Least Square) } \\
\text { method using E-Views } 6 \text {. The results of this research indicate that the Rupiah exchange rate and the } \\
\text { GDP growth of the export destination countries have a positive relationship but are insignificant to } \\
\text { the manufacturing exports, while the inflation rate is negative and insignificant to the value of } \\
\text { manufacturing exports. Meanwhile, the raw material import has a significant positive effect on } \\
\text { manufacturing exports. This shows that the Indonesia's manufacturing exports still depend on the } \\
\text { imported raw materials. Related to this fact, the government must take a strategic step in the short } \\
\text { term to increase the non-oil exports, especially the exports of manufactured products that are the } \\
\text { high value-added export products. }\end{array}$ \\
\hline
\end{tabular}

\footnotetext{
$凶$ Corresponding Author:

Journal's Room, L Building, FE UNNES Sekaran Gunungpati

Semarang 50229, Indonesia

E-mail: nin.08.nin@gmail.com
} 


\section{INTRODUCTION}

Based on the theory of economics, international trade consisting of exports and imports is one of the keys to a country's economic growth, besides consumption, investment, and government spending. Historically, the economic growth in the developed countries is very supported by the export growth so that the countries dominate the world market share (Lubis, 2013).

Export is one important benchmark to know how much the economic growth of a country is. From this export activity, the business activity in the real sector will be more developed. The products produced in the country do not only rotate in the country alone but can be sold in the international trade. Therefore, in the long term the export activities can be a hero of foreign exchange for the country's economic growth

Indonesia's export value has fluctuated considerably over the last ten years. The greatest export value was in 2011, with the total value of exports reached US $\$ 203.6$ billion, or increase of $29.1 \%$ compared to the year of 2010 . The value is two times greater than the value of Indonesia's exports in the previous five years in 2006. This achievement is very glorious considering that Indonesia is one of the few countries that can double its export value within five years. However, after this high achievement, Indonesia's exports have been steadily declining for the next four years. The total export value in 2015 was only US \$ 148.4 billion or decreased $27.12 \%$ compared to 2011 .

The commodity that has the greatest contribution to the total exports is the manufacturing exports accounted for $72 \%$ with a value of USD 106.19 billion. The second position of $23 \%$ was obtained from the mining results with a value of USD 33.68 billion. Furthermore, the agricultural products contributed $4 \%$ with a value of USD 5.76 billion, and the exports from other sectors were $1 \%$ with a value of US $\$ 1.40$ billion.

Indonesia uses a system of floating exchange rate. If the exchange rate is depreciated in which the value of the domestic currency decreases and the exchange rate (price) of the value of the foreign currency increases, it will cause the exports increase and the imports tend to decrease (Sukirno, 2002). So if the exchange rate of Rupiah against USD is depreciating, it will increase the export of Indonesian products abroad. It is because from the point of view of the export destination countries, the price of the Indonesian products tends to be cheaper than the export products from other countries, so this will increase the competitiveness of the Indonesian exports.

Throughout the year of 2014 to 2015, the exchange rate fluctuated with a tendency to depreciate against the US dollar to touch the rate of Rp 13,795. With the depreciation of Rupiah against the US dollar, many parties expect that the number of Indonesian exports can be increased, because with the depreciation of Rupiah, the competitiveness of the Indonesian products will increase in the world market. However, the reality is not like the expectation. Indonesia's manufacturing export performance as a sector that has the greatest contribution to the total exports tends to decrease as seen from the movement in 2011 and the significant decrease until the end of 2015.

The poor export performance is inseparable from the global economic condition that is not supportive amid the weakening of the economy in some export destination countries, also the decrease in commodity prices that have been the mainstay of the Indonesian exports. The products through the manufacturing process in the country also do not show a positive export growth during the period of decrease in the value of Rupiah. This is related to the raw material of the product that still depends a lot on the imports.

The development of Indonesia's raw material imports over the last ten years is as follows. The raw material imports contribute substantially to the total imports. Of the total imports of industrial products in 2012 worth USD 189.14 billion, about $67 \%$ of which is the import of raw materials. The raw material imports experienced a very significant jump in 2014 - 2015 to affect the total imports and make Indonesia Trade Balance deficit. This fact is very worrying because the manufacturing industry in 
the country has a very high dependence on the materials from other countries.

The depreciation of Rupiah exchange rate cannot spur the value of Indonesia's manufacturing exports. Based on the above description, the writers are interested in conducting a research submitted in this thesis entitled "Determinant Analysis of Decrease in Manufacturing Export Value amid Depreciation of Rupiah Exchange Rate"

\section{RESEARCH METHOD}

The data used in this research is time series data of quarterly period of 2006 Q1 - 2015 Q4 with the time sample of January 2006 - December 2015. The source of data is obtained from the monthly report and the annual report published by Bank Indonesia, IFS (International Financial Statistic) and World Bank use the Ordinary Least Square (OLS) analysis method. Data processing uses the Eviews 6.0, but it also uses the Microsoft Excel software as the auxiliary software in converting the data into the raw form, which is provided by the source, into the more representative form to use on the main software to minimize the errors.

Mathematically the basic model used in this research is as follows:

$\begin{array}{ll}\text { EX_M = f(REER,INF,IM_BB,GDP_IM } \\ \text { In which : } \\ \text { EX_M } & \text { : Indonesia's Manufacturing } \\ & \text { Exports } \\ \text { REER } & \text { : Exchange Rate } \\ \text { INF } & \text { : Inflation } \\ \text { IM_BB } & \text { : Raw material imports } \\ \text { GDP_IMP } & \text { : GDP importer }\end{array}$

And the equation is :

$\mathrm{EX} \_\mathrm{M}=\mathrm{a}_{0}+\beta_{1} \mathrm{REER}+\beta_{2} \mathrm{INF}+\beta_{3} \mathrm{IM} \_\mathrm{BB}+$ $ß_{4}$ GDP_IM + Ui

\section{RESULTS AND DISCUSSION}

The industrial sector is expected to become the driving force for the national economy considering that the richness of Indonesia's natural resources with the comparative advantage is the primary product that needs to be processed to be the manufacturing industry products to increase the added value. According to the Ministry of Industry, the contribution of the manufacturing industry should be at least $40 \%$ to GDP. If the rate can be reached, Indonesia can claim to be a country with a strong industry. The contribution is the highest among other sectors.

Regarding the latest export growth, the position of Indonesia's export value in 2015 reached USD 148.36 billion supported by US \$ 106.19 billion of the manufactured exports or contributed about $72 \%$ to the total exports. The total export position decreased by $22.3 \%$ compared to the year of 2011 from USD 191.11 billion and the manufactured exports also decreased by $8.32 \%$ from USD 115.82 billion.

The Rupiah exchange rate fluctuated with a tendency to depreciate against the US dollar. In five years Rupiah was the strongest value at $\mathrm{Rp}$ 8,560 / USD in 2011 at quarter III and its weakest value is at Rp 13.850 / USD in 2015 at quarter III. In other words, in 2015 the Rupiah exchange rate was depreciated by $61.80 \%$ against the US dollar compared to the year of 2011.

Inflationary developments show fluctuating movements. In early 2006 the inflation was at the highest point in the period of $2006-2015$ of $16.90 \%$. The inflation increased amid 2008 of $11.96 \%$. Based on the types, the inflation in that year was included in Galloping Inflation or double-digit inflation, in which people began to doubt, the purchasing power decrease, and the value of currency would decrease. The inflation began to be stable in 2009 to 2015 with a rate of $2.29 \%-7.76 \%$. In the export of goods, the inflation affects the good production cost, taxes, customs, and other barrier entries in the trade among the countries. In a state of inflation the competitiveness of exports would be reduced

Indonesia has the ten greatest destination countries for the exported products of the manufacturing industry, including: the United States, China, Japan, Singapore, India, Malaysia, Thailand, South Korea, the Netherlands and Australia. The United States is the greatest export destination country for Indonesia followed by China and Japan. Among 
the ten countries, the United States is the only country that has a positive trend in the growth of import value from Indonesia for exporting the manufactured products.

The export of a country is the import of another country. With prices considered fixed, the exports depend on the foreign revenues rather than the country's national income (Nopirin, 2010: 241). It means, the demand for Indonesian exports is one of which influenced by the level of income of the importing countries. A country's income is also called GDP (Gross Domestic Gross) as a parameter of the global economic growth.

After testing the classical assumption, it can be stated that the linear regression model used is free of disease or it meets the requirement to produce a good estimate or it is known as BLUE. The regression result with Least Square Method is as follows

From the regression result, an equation is formed as follows:

LNEX_M $=2.867206+0.034372$ REER 0.006706 INF + 0.654444 LNIM_BB + 0.003733 LNGDP_GR

The regression result from the effect of the exchange rate, the inflation, the raw material import, and the GDP growth on the manufacturing exports shows R2 value of 0.939873 . It means that $93.99 \%$ of the manufacturing export value can be explained by the exchange rate, the inflation, the raw material imports, and the importer GDP growth, while $6.01 \%$ is explained by other variables outside the model.
The regression results in table 1 show the F-statistic probability value of 0.0000 significant at $\alpha=1 \%$. It means that the exchange rate, the inflation, the raw material imports, and the importer GDP growth have a significant effect on manufacturing exports.

Based on the analysis results, it is explained that the exchange rate variable has a negative but not significant effect with a coefficient of 0.034372 to the export of manufacturing. That is, the exchange rate does not have a significant effect on the value of Indonesia's manufacturing exports. This shows that the exchange rate has not been able to influence the increase in export value of manufacturing.

The results of the analysis show that inflation has a negative but insignificant effect on the manufacturing exports with a coefficient of 0.006706 in which the increase of $1 \%$ in the domestic inflation rate will lower the value of Indonesian manufacturing exports of 0.0067 USD.

The raw material imports have a significant positive effect on the manufacturing exports with a coefficient of 0.654444 . The raw material imports proven to have significant effect on the manufacturing exports show that our industry still heavily depends on the raw materials coming from abroad, in which Indonesia's balance of payments has ever experienced a budget deficit in 2012 due to a surge in the import value of the raw materials, the auxiliary materials, and the capital.

Table 1. Regression Result

\begin{tabular}{llccc}
\hline Variable & Coefficient & Std. Error & t-Statistic & Prob. \\
\hline GDP_GR & 0.003733 & 0.004791 & 0.779119 & 0.4411 \\
INF & -0.006706 & 0.003164 & -2.119213 & 0.0412 \\
LNIM_BB & 0.654444 & 0.032551 & 20.10507 & 0.0000 \\
LNREER & 0.034372 & 0.074106 & 0.463830 & 0.6456 \\
C & 2.867206 & 0.705021 & 4.066836 & 0.0003 \\
R-squared & & & & \\
Adjusted R-squared & 0.939873 & & & \\
F-statistic & 0.933001 & & & \\
Prob(F-statistic) & 136.7742 & & & \\
Durbin-Watson stat & 0.000000 & & & \\
& 1.052849 & & & \\
\hline
\end{tabular}


. Based on the regression result, it is found that GDP growth of the importer countries has a positive but not significant effect on the manufacturing exports. It has not proven yet the theory that a country's exports are another country's imports. Considering the prices are fixed, the exports depend more on the foreign revenues rather than on the country's national income (Nopirin, 2010: 241). The unfulfilled condition of the Indonesia's manufacturing exports in recent years is more to the lack of competitiveness where the resulting products are less competitive

\section{CONCLUSION}

Based on the results of data research on the Determinant Analysis of Decrease in Manufacturing Export amid Depreciation of Rupiah Exchange Rate, the following conclusion is obtained: The exchange rate variable has a negative but insignificant effect on the Indonesia's manufacturing exports. It shows that the Indonesia's manufacturing export performance does not depend on the exchange rate, so when the exchange rate is depreciated, it does not make the manufacturing export increase, the inflation variable has a negative and significant effect on the value of Indonesia's manufacturing exports. An increase in inflation will decrease the value of Indonesia's manufacturing exports, the raw material import variable has a positive and significant effect on the manufacturing exports. If the raw material imports increase, the manufacturing exports will increase. It is because most of the raw materials for the manufacturing industry still depend on the imports, the GDP growth variable of the importer or the export destination country has a positive but insignificant effect on the Indonesia's manufacturing exports, the independent variables consisting of the exchange rate, the inflation, the raw material imports, and GDP growth of the importer have a significant and statistical effect on the Indonesia's manufacturing exports.

The depreciation of the exchange rate has not been able to increase the manufacturing exports in Indonesia. The competitiveness of the manufactured products is still low compared to the products from other countries. Indonesia's manufacturing industry is more dependent on the imported raw materials. This will make the producers or manufacturers difficult when there is an increase in the price of the imported raw materials. These factors lead to great increase in the production costs so that the price of our manufactured products is difficult to compete in the international market. It would be better if the government tries to supply the raw materials through the development of domestic substitution industry, in which besides reducing the production costs it will also reduce the level of raw material imports.

The government should continue to invite the real sector actors, especially the business actors and exporters of the manufacturing industry to synergize with the government to undertake a strategic breakthrough in the short period in order to increase the exports, especially the exports of manufactured products that are the high value added export products

\section{REFERENCES}

Adisaputro, Gunawandan Marwan Asri, 2003. Anggaran Perusahaan, Buku 1, Penerbit BPFE, Yogyakarta.

Bank Indonesia.2016.Statistik Ekonomi dan Keuangan Indonesia (online). (www.bi.go.id)

Basri, Faisal, 2002, Perekonomian Indonesia: Tantangan dan Harapan bagi Kebangkitan Indonesia, Erlangga :Jakarta

Boediono, 2001.Ekonomi Makro. Edisi-4.penerbit BPFE: Yogyakarta.

Deliarnov, Nicholson, Walter. 2005, Teori Ekonomi Mikro I, Terjemahan Deliarnov, Rajawali.:Jakarta

Salvatore, Dominick. 1997. Ekonomi Internasional, alih bahasa oleh Haris Munandar edisi 5 cetak 1. Erlangga :Jakarta

Gujarati, Domodardan Porter, C. Dawn. 2010. Dasardasar ekonometrika. Salemba Empat: Jakarta

Ito, Takatoshi., Sato, Kiyotaka. 2008. Exchange Rate Changes and Inflation in Post-Crisis Asian Economies: Vector Autoregression Analysis of the Exchange Rate Pass-Through. Journal of Money, Credit and banking Vol. 40 (7) pp. 14071438. 
Krugman R. Paul danObstfeld Maurice, 2005.Ekonomi Internasional Teori dan Kebijakan Jilid 2. Rajawali Pers: Jakarta [penerjemah: Dr. Faisal H Basri,SE. M.Sc]

Kuncoro, Mudrajat, 2007. Ekonomika Industri Indonesia: Menuju Negara Industri Baru 2030, Andi, Yogyakarta.

International Monetary Fund. 2016. International Financial Statistics (online). (www.imf.org)

Lipsey, R. G., P. N. Courant, D. D. Purvis, dan P. O. Steiner. 1995. Pengantar Makro Ekonomi. Erlangga: Jakarta.

Lubis, Andrian D. 2013.Analisis Faktor yang Mempengaruhi Kinerja ekspor Indonesia. Penelitian pada Pusat Penelitian dan Pengembangan Perdagangan Luar Negeri. Jakarta

Nopirin, 2000. Pengantar Ilmu Ekonomi Makrodan Mikro. BPFE UGM. Yogyakarta.

Nopirin. 2010. Ekonomi Internasional Ed.3. Yogyakarta: BPFE

Siregar, Reza., Rajan, Ramkishen S. 2004. Impact of exchange rate volatility on Indonesia's trade performance in the 1990s. Journal of the Japanese and International Economies, Vol 18 (2) pp. 218240

$\mathrm{Wu}$, Ying. 2000. Stock prices and exchange rates in VEC model-The case of Singapore in the 1990s. Journal of Economics and Finance. Vol 24 (3) pp 260-274. 